\title{
IMPROVING MOTIVATION AND LEARNING ACHIEVEMENTS WITH VEE DIAGRAM IN SALT HYDROLYSIS MATERIAL AT SENIOR HIGH SCHOOL SUKOMORO
}

\author{
Soekristin Prasetyowati
}

\author{
SMA Negeri 1 Sukomoro, Magetan
}

soekristinprasetyowati@yahoo.co.id

\begin{abstract}
This study aims to describe the use of vee diagrams in an effort to increase motivation and learning achievement in Chemistry class XI.A.1 Sukomoro 1 Senior High School in the material of Salt Hydrolysis. This research is a classroom action research (CAR) which is carried out in two cycles, each cycle consisting of the stages of planning, implementation, observation and reflection. The research is a quasi experiment with a quantitative approach. The research design is Postest-Only Control Design. The object of the study was all students of class XI.IPA.I of Senior High School Sukomoro in the 2015/2016 school year. Data collection techniques use test methods, and observation methods. The results showed that chemical learning using vee diagrams can increase motivation and learning achievement of Chemistry students in class XI.IPA.1 in Salt Hydrolysis material. In cycle 1 the average cognitive value of 71.05 becomes 80 in cycle 2, learning Chemistry using vee diagrams can be carried out well and can improve student learning motivation especially students gain real experience in everyday life.
\end{abstract}

Keywords : motivation, learning achievement, diagram vee, hydrolysis of salt

\section{PENDAHULUAN}

Piagetmerupakan salah satu pioner konstruktivis, ia berpendapat bahwa anak membangun sendiri pengetahuannya dari pengalamannya sendiri dengan lingkungan. Dalam pandangan Piaget, pengetahuan datang dari tindakan, perkembangan kognitif sebagian besar bergantung kepada seberapa jauh anak-anak aktif memanipulasi dan aktif berinteraksi dengan lingkungannya. Sesuai dengan Kurikulum 1994 Pembelajaran Sains diarahkan pada pendekatan keterampilan proses [1]. Konstruktivisme dan Teori Piaget merupakan teori pembelajaran yang melandasi pembelajaran sains, termasuk pembelajaran Kimia, mulai dari input, proses dan hasilnya mengacu pada teori Piaget [2]. Pada Kurikulum sekarang pembelajaran Kimia disusun berbasis kompetensi, yang kompetensinya harus dikembangkan sesuai dengan tahap perkembangan intelektual sebagaimana dikemukakan Piaget. Pengetahuan fisik dan logika tidak dapat diteruskan dalam bentuk sudah jadi. Setiap anak harus membangun sendiri pengetahuan ini dengan dasar struktur kognitif yang telah ada sebelumnya[3].
Konsep-konsep dasar dalam pembelajaran sains hendaknya diusahakan di"bangun" (di"construct') sendiri oleh siswa dan dikembangkan secara mandiri, baik melalui transfer pengetahuan maupun pengamatan langsung terhadap gejala alam. Semua ini akan diolah secara kognitif dan pada akhirnya akan menghasilkan perubahan perilaku pula[4].Pada dasarnya pendekatan konstruktivistik menekankan proses membangun sendiri konsep-konsep yang dipelajari oleh siswa (student oriented). Begitu juga seperti yang dicatat Gowin bahwa siswa tidak dapat menjelaskan makna dari hasil penemuan mereka dan menghubungkan dengan teori yang sesuai tanpa pendekatan dan alat pembelajaran yang dapat memfasilitasi peran aktif siswa dalam proses pembelajaran[5].

Teori yang di dapat siswa akan bermakna bila siswa memanfaatkan dalam kehidupan nyata mereka masing-masing. Atau dalam pengertian sempit dalam proses pembelajaran ilmu yang diperoleh siswa hendaknya berdampak dengan penemuan yang akan dilakukan siswa dalam kehidupan nyata mereka. Dengan kata lain teori yang didapat di kelas dapat dibuktikan dalam kehidupan nyata 
siswa. Misal bila dalam pembelajaran Kimia materi $\mathrm{pH}$ untuk larutan asam kurang dari 7, maka siswa dapat membuktikannya dalam kehidupan mereka bila $\mathrm{pH}$ kurang dari 7 bersifat asam dengan ditandai perubahan warna indikator yang dipakai, misal kertas lakmus biru berubah menjadi merah, atau bila diukur dengan indikator universal, perubahan warna dari kertas indikator universal menunjuk pada $\mathrm{pH}$ kurang dari 7.

Banyak materi Kimia yang mempunyai karakterisitk bersifat abstrak, atau peristiwaperistiwa kimiawi banyak yang tidak bisa dilihat dengan kasat mata, seperti asam menghasilkan ion $\mathrm{H}^{+}$dalam pelarut air, keberadaan ion $\mathrm{H}^{+}$tidak bisa dilihat dengan kasat mata, tetapi gejalanya dapat dibuktikan dengan kertas lakmus biru menjadi merah. Sedang basa menghasilkan ion $\mathrm{OH}^{-}$dalam pelarut air, keberadaan ion $\mathrm{OH}^{-}$tidak bisa dilihat dengan kasat mata, tetapi gejalanya dapat dibuktikan dengan kertas lakmus merah menjadi biru. Teori seperti itu bila hanya sekedar teori yang diterima siswa tidak akan memberi makna yang dapat berdampak perubahan perilaku siswa. Tetapi bila siswa diberi kesempatan untuk membuktikan dalam kehidupan nyata mereka, teori tersebut akan dibawa sampai akhir hayat mereka. Banyak siswa yang belum tuntas pada materi Kimia disebabkan antara lain pengalaman belajar mereka dalam kehidupan nyata masih minim. Siswa masih belum memahami makna soal dalam evaluasi. Berdasarkan wawancara peneliti pada siswa, jawaban mereka sebagian besar masih bingung mamaknai soal, atau mengerti maksud soal yand dihadapi, sehingga jawabannya masing banyak yang salah. Akibatnya secara klasikal pembelajaran belum tuntas.

Peneliti sebagai guru di SMA Negeri 1 Sukomoro, sudah mencoba menggunakan model pembelajaran dan strategi pembelajaran yang memungkinkan untuk pembelajaran Kimia pada Kompetensi Dasar Hidrolisa Garam, tetapi hasil akhir secara klasikal belum tuntas, sebagian besar siswa di kelas XI.A.1 masih merasa bingung atau belum sepenuhnya memahami soal-soal dalam setiap evaluasi. Materi hidrolisis garam secara teori siswa dapat menganalisa sifat garam, tetapi belum pernah dibuktikan kebenaran teori tersebut, mereka bisa memprediksikan sifat garam dari sifat asam dan basa yang membentuknya, apakah dari asam kuat basa lemah, ataukah dari asam lemah basa kuat dan dari asam lemah dan basa lemah, tetapi prediksi mereka hanya sampai prediksi tanpa ada pembuktian. Sedang siswa yang belum paham, belum termotivasi untuk berusaha mencari tahu jawaban dari setiap permasalahan.

Peran penting motivasi belajar dan pembelajaran, antara lain: 1) Motivasi dapat berperan dalam penguatan belajar apabila seorang anak yang sedang belajar dihadapkan pada suatu masalah yang menentukan pemecahan dan hanya dapat dipecahkan berkat bantuan hal-hal yang pernah dilalui. 2) Motivasi dapat memperjelas tujuan belajar erat kaitannya dengan kemaknaan belajar. Anak akan tertarik untuk belajar sesuatu, jika yang dipelajari itu sedikitnya sudah dapat diketahui atau dinikmati manfaatnya oleh anak. 3) Seorang anak yang telah termotivasi untuk belajar sesuatu berusaha mempelajari dengan baik dan tekun dengan harapan memperoleh hasil yang lebih baik [6].Fungsi motivasi itu meliputi :1) Mendorong timbulnya kelakuan/ suatu perbuatan. 2) Motivasi berfungsi sebagai pengarah, artinya mengarah pada perbuatan ke pencapaian tujuan yang diinginkan. 3) Motivasi berfungsi sebagai penggerak, artinya sebagai motor penggerak dalam kegiatan belajar. Dari pendapat di atas dapat disimpulkan bahwa peran dan fungsi motivasi belajar adalah sebagai pendorong usaha dan pencapaian prestasi sehingga untuk mencapai prestasi tersebut peserta didik dituntut untuk menentukan sendiri perbuatan-perbuatan apa yang harus dilakukan untuk mencapai tujuan belajarnya. Dari pandangan tersebut peneliti mempunyai pandangan bahwa siswa SMA Negeri 1 Sukomoro belum memiliki motivasi belajar yang dapat menguatkan belajar, dapat memperjelas tujuan dengan kemaknaan belajar, dan memperoleh hasil yang baik dari belajar mereka.

Pembelajaran Kimia pada materi Hidrolisa Garam di SMA Negeri 1 Sukomoro belum menggunakan alat atau media yang bisa menjembatani atau memperkuat pemahaman siswa terhadap teori tersebut. Sehingga pada saat mereka menghadapi soal mereka mempunyai keyakinan untuk menjawab 
dengan benar. Selain itu banyak hasil-hasil penelitian yang menggunakan diagram Vee menyimpulkan bahwa penggunaan diagram Vee pada pembelajaran Sains memberikan dampak yang signifikan pada peningkatan aktivitas belajar dan prestasi belajar siswa. Seperti penelitian yang dilakukan oleh Puspita Mega Sari yang menyimpulkan bahwa terdapat pengaruh yang signifikan penggunaan diagram Vee pada prestasi belajar siswa pada materi Larutan Penyangga. Begitu juga penelitian yang dilakukan oleh Apni Viyandari yang menyimpulkan bahwa terdapat perbedaan prestasi belajar kognitif siswa yang dikenai pembelajaran berbasis masalah dengan menggunakan diagram vee komik. Hal ini merupakan tantangan bagi peneliti untuk mencoba memperbaiki pembelajaran yang bisa memungkinkan siswa memperkuat teori yang mereka dapat untuk menghadapi kehidupan nyata mereka, sehingga pembelajaran menjadi bermakna.

Fungsi Diagram Vee adalah menolong siswa untuk melihat interaksi antara teori, metode dan hasil. Diagram Vee adalah seperti advance organizer dalam meningkatkan organisasi yang kuat pada struktur kognitif. Diagram Vee yang diselesaikan siswa bertindak sebagai laporan laboratorium mereka dan memudahkan bagi guru untuk merespon daripada laporan laboratorium tradisional. Bentuk $\mathrm{V}$ dalam Diagram Vee bukan suatu keharusan, dan bisa dibuat dalam bentuk garis lurus, lingkar, ataupun bentuk yang lain akan tetapi yang lebih ditekankan adalah bahwa Diagram Vee pada dasarnya merupakan metode untuk membuat hubungan antara 'thinking' dan 'doing' yang terjadi selama di laboratorium [5].Diagram Vee menghubungkan antara penemuan hasil kegiatan praktikum di laboratorium dengan konsep dan teori yang terkait. Dengan mengacu pada pertanyaan, siswa diajak untuk menemukan hubungan antara struktur ilmu pengetahuan yang mereka temukan di laboratorium dengan konsep dan teori tentang ilmu pengetahuan yang terkait. Diagram Vee lebih menarik siswa untuk berpikir lebih dalam mengenai hubungan antara aktivitas yang mereka kerjakan di laboratorium dengan teori yang terkait. Diagram Vee yang diselesaikan siswa bertindak sebagai laporan laboratorium mereka dan memudahkan bagi guru untuk merespon daripada laporan laboratorium tradisional. Diagram vee mempunyai poin-poin yang harus dipenuhi diantaranya : 1) pertanyaan focus, 2) teori dan konsep yang diperkirakan dapat mendukung kearah jawaban pertanyaan. 3) kegiatan penyelidikan dengan melakukan pengamatan, membuat catatan, menstranformasi catatan hingga membuat kesimpulan yang berupa klaim pengetahuan 4) menyampaikan hasil penyelidikan berupa klain pengetahuan agar mendapatkan pengetahuan dan aplikasi pengetahuan yang benar.

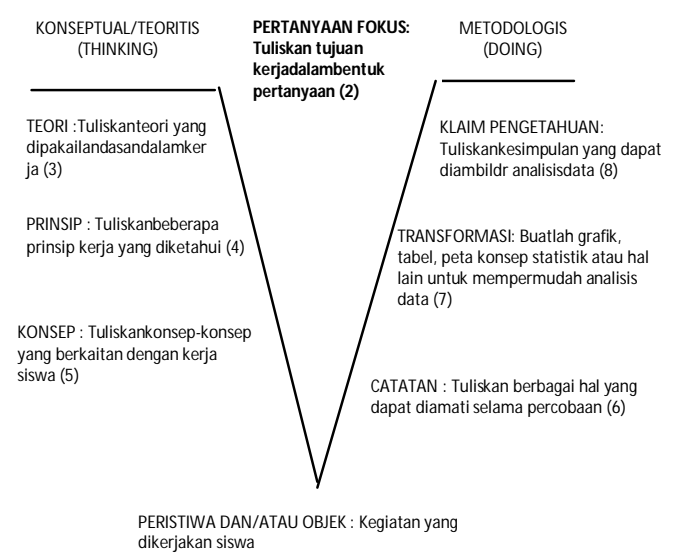

Gambar 1. Bentuk diagram Vee

\section{METODE}

Pelaksanaan penelitian dilaksanakan selama dua siklus masing-masing siklus terdiri dari 3 pertemuan. Prosedur penelitian terdiri dari empat langkah yaitu perencanaan, pelaksanaan, pengamatan dan refleksi.

Penelitian ini menggunakan 2 siklus dengan mengikuti model Classroom Action Research Kemmis dan Taggart. Penelitian ini dilakukan di SMA Negeri 1 Sukomoro Magetan, Propinsi Jawa Timur pada tahun pelajaran 2015/2016 semester genap. Alasan pemilihan lokasi ini adalah rata-rata prestasi belajar belum memenuhi kriteria ketuntasan minimal (rata-rata di bawah 76\%). Penelitian ini dilakukan pada semester genap tahun 2015/2016 yang disesuikan dengan alokasi penyampaian kompetensi dasar Hidrolisis Garam.

Teknik pengumpulan data pada penelitian ini terdiri atas : 
1. Metode observasi, metode ini digunakan untuk mengukur motivasi kemampuan psikomotor peserta didik selama eksperimen dan penilaian afektif peserta didik selama diskusi maupun pembelajaran. Observasi dilakukan dengan menggunakan lembar pengamatan terhadap motivasi belajar juga kerja individu dalam kelompok selama melakukan kesperimen tentang penentuan $\mathrm{pH}$ garam.

2. Metode Evaluasi, metode ini digunakan untuk mengukur hasil belajar peserta didik setelah prosespembelajaran berakhir.

Instrumen yang dipakai pada pelaksanaan penelitian, adalah :

1. Lembar Kegiatan Siswa, sebagai alat bantu materi Hidrolisa Garam dengan menggunakan media diagram vee.

2. Tes Akhir Pembelajaran berbentuk pilihan ganda, sebagai alat mengukur penguasaan konsep Hidrolisa Garam.

Data hasil penelitian tindakan kelas ini akan dianalisis secara kuantitatif dengan melihat persentase peningkatan motivasi belajar dan hasil belajar siswa. Selanjutnya berdasarkan hasil analisa tersebut dilakukan tindak lanjut. Data yang diperoleh dari tes prestasi siswa akan digunakan untuk mengambil kesimpulan terhadap hasil penelitian tindakan kelas.

Indikator keberhasilan sebagai berikut : 1) Dalam proses pembelajaran sekurangkurangnya $76 \%$ siswa termotivasi. 2) Kondisi dalam proses pembelajaran sekurangkurangnya $76 \%$ siswa dapat menjawab kuis dan pertanyaan yang diberikan tentang Hidrolisa garam. 3) Kriteria Ketuntasan Minimal (KKM) siswa sama dengan 76.

\section{HASIL DAN PEMBAHASAN}

\section{A. Hasil Penelitian}

\section{Siklus 1}

\section{Tahap Perencanaan}

Pada silkus 1 dilaksanakan dalam 3 pertemuan (dengan alokasi waktu setiap pertemuan 2 x 45 menit) yaitu pada tanggal 8 Maret 2016, 10 Maret 2016 dan 22 Maret 2016. Dengan berpedoman pada kurikulum tingkat satuan pendidikan, peneliti melakukan langkah - langkah perencanaan pembelajaran dengan RPP dengan menggunakan media diagaram vee, yaitu : 1) Standar kompetensi, 2) Kompetensi Dasar, 3) Membuat Lembar Kerja Siswa (LKS) dan Lembar Diskusi Siswa (LDS), 4) Membentuk kelompok peserta didik.

\section{Tahap Pelaksanaan / Pengamatan}

Pada tahap ini sesuai dengan rancangan pembelajaran pada RPP menggunakan media diagram vee, pada pertemuan pertama $(2 \times 45)$ terdiri atas : a. Orientasi ( 5 menit) Sebelum pembelajaran guru terlebih dahulu menyampaikan tujuan pembelajaran dan memotivasi siswa dengan mengulang materi reaksi penggaraman (reaksi antara asam dan basa), kemudian membagi siswa ke dalam kelompok diskusi . b. Ekplorasi ( 70 menit ) Guru memberi informasi terjadinya reaksi hidrolisis pada kation dan anion dari asam dan basanya, memberi kesempatan pada siswa untuk berdiskusi tentang permasalahn yaitu menentukan sifat garam yang terbentuk rekasi asam dan basa dan menghitung pHnya. Secara kelompok siswa berdiskusi tentang sifat garam dari reaksi asam dan basa dan pHnya. c. Konfirmasi ( 15 menit ) Guru meminta peserta didik untuk mengkomunikasikan hasil diskusi. Pertemuan kedua a) Orientasi( 5 menit) Guru mengulas kembali materi pelajaran yang lalu dan membagi kelompok eksperimen. b) Ekplorasi (70 menit). Siswa diberi kesempatan untuk bereksperimen menentukan sifat garam dan $\mathrm{pH}$ suatau garam (garam yang berasal dari asam lemah dan basa kuat) yang sudah ditentukan secara teori pada pertemuan yang lalu. Siswa mencatat hasil eksperimen. c) Konfirmasi. ( 15 menit ) Guru meminta peserta didik untuk mengkomunikasikan hasil eksperimen. Pertemuan ketiga a) Orientasi( 5 menit) Guru mengulas kembali materi pelajaran yang lalu dan membagi kelompok . b) Ekplorasi (70 menit). Siswa diberi kesempatan untuk menggabungkan hasil diskusi dengan eksperimen ke dalam diagram vee sifat garam dan $\mathrm{pH}$ suatu garam yang berasal dari asam lemah dan basa kuat). Siswa membuat diagram vee. c) Konfirmasi. (15 menit) Guru meminta peserta didik untuk mengkomunikasikan diagram vee yang dibuat. 


\section{Tahap evaluasi}

Pada tahap ini peneliti sekaligus sebagai guru mengadakan evaluasi dengan memberikan tes tulis (bentuk pilihan ganda). Hasil pengamatan dan evaluasi dapat dilihat pada diskripsi data sebagai berikut :

\section{a. Data nilai prestasi belajar kognitif dan psikomotor}

Data prestasi belajar kognitif dalam penelitian ini diperoleh setelah siswa melakukan pembelajaran materi Hidrolisa garam dengan eksperimen dan diskusi hasil eksperimen. Setelah akhir pembelajaran siswa diadakan evaluasi terhadap penguasaan konsep. Deskripsi data prestasi belajar kognitif dan psikomotor pada siklus 1 dapat dilihat dalam tabel dan histogram berikut :

Tabel 1 Data hasil belajar kognitif dan Psikomotor pada siklus 1

\begin{tabular}{|c|c|c|c|}
\hline \multicolumn{4}{|c|}{ Statistics } \\
\hline & & $\begin{array}{c}\text { Prestasi } \\
\text { belajar } \\
\text { kognitif_- } \\
\text { siklus1 }\end{array}$ & $\begin{array}{c}\text { Prestasi } \\
\text { belajar } \\
\text { psikomotor_- } \\
\text { siklus1 }\end{array}$ \\
\hline & Valid & 20 & 20 \\
\hline & Missing & 16 & 16 \\
\hline & & 71,05 & 74,70 \\
\hline & & 70,00 & 78,00 \\
\hline & & 9,891 & 10,311 \\
\hline & & 50 & 54 \\
\hline & & 84 & 88 \\
\hline
\end{tabular}

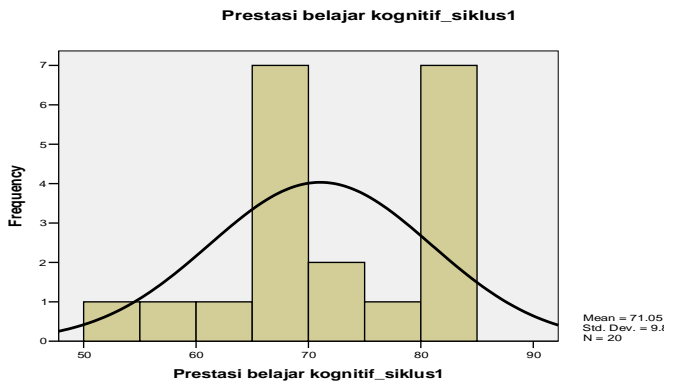

\section{Gambar 1 Histogram nilai kognitif siklus 1}

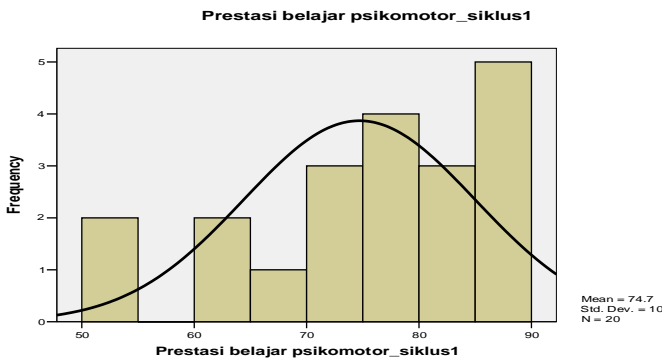

Gambar 2 Histogram nilai psikomotor siklus 1
Untuk data hasil pengamatan motivasi belajar siswa pada siklus 1 adalah sebagai berikut:

Tabel 2 Skor Hasil Pengamatan Motivasi Belajar Siswa pada Siklus 1

\begin{tabular}{clcc}
\hline No & Nama Siswa & $\begin{array}{c}\text { Rata-rata } \\
\text { skor } \\
\text { motivasi } \\
\text { siklus I }\end{array}$ & Kriteria \\
\hline 1 & Abidin Fajar Ashari & 78 & Cukup \\
\hline 2 & Agustina Purnama & 78 & Cukup \\
\hline 3 & Alfian Dian & 72 & Kurang \\
\hline 4 & Ali Fahrudin & 78 & Cukup \\
\hline 5 & Antika Dwi Hapsari & 81 & Baik \\
\hline 6 & Arief Krisna & 72 & Kurang \\
\hline 7 & Arif Abdul & 67 & Kurang \\
\hline 8 & Ayu Dian Pratiwi & 67 & Kurang \\
\hline 9 & Bagus Iryawan & 67 & Kurang \\
\hline 10 & Bambang Triatmojo & 78 & Cukup \\
\hline 11 & Bayu Abdi & 93,75 & Sangat Baik \\
\hline 12 & Bening Fitri & 78 & Cukup \\
\hline 13 & Bimma Ridho & 72 & Kurang \\
\hline 14 & Bramantya Ranu Z & 72 & Kurang \\
\hline 15 & Denis Eka W & 67 & Kurang \\
\hline 16 & Desi Milasari & 67 & Kurang \\
\hline 17 & Desindra Mala Dwi & 93,75 & Sangat Baik \\
\hline 18 & Devia Reza & 67 & Kurang \\
\hline 19 & Devi Indra & 78 & Cukup \\
\hline 20 & Dian Ariska & 67 & Kurang \\
\hline & & & \\
\hline
\end{tabular}

\section{Tahap Refleksi}

Berdasarkan kegiatan penelitian pada siklus I mulai dari perencanaan, pelaksanaan dan pengamatan, maka peneliti menganalisis hasilnya secara umum pembelajaran Kimia pada materi Hidrolisa Garam dengan menggunakan diagram vee belum meningkatkan motivasi belajar dan hasil belajar siswa. Dalam pelaksanaan Pembelajaran siklus I masih ada kendala serta masalah yang ditemukan.

Kendala yang dihadapi: 1) Guru belum maksimal mengalokasikan pemanfaatan diagram vee dengan baik 2) Guru belum optimal memantau kegiatan peserta didik karena masih banyak siswa yang membutuhkan bimbingan guru untuk membuat diagram vee. 3) Masih ada siswa yang tidak terlibat dalam kerja atau diskusi kelompok 4) Peserta didik kurang menguasai teknik membuat larutan suatu garam dari asam lemah dan asam kuat, sehingga hasilnya kurang tepat. 5) Peserta didik belum menguasai bekerja di laboratorium terutama penggunaan pipet tetes yang masih bercampur untuk beberapa larutan, selain itu keakuratan mengamati $\mathrm{pH}$ larutan yang terjadi kurang tepat sehingga hasilnya dalam diagram vee belum maksimal 6) Guru kurang memotivasi untuk berkreatifitas dalm belajar. Berdasarkan kendala-kendala tersebut, pada siklus 1 masih terdapat permasalahan, 
yaitu: 1) Anak kurang memperhatikan pembelajaran, 2) Anak kurang percaya diri dalam berkesperimen, 3) Anak merasa ragu dan canggung memegang alat eksperimen, 4) Anak tidak mendapatkan kepuasan atas hasil kerjanya, 4) Anak enggan belajar Kimia karena menganggap/merasa sulit, 5) Anak tidak berminat atau malas. Dari hasil tes tulis masih banyak siswa yang belum tuntas.

Dari temuan-temuan yang diperoleh pada siklus 1, peneliti menganggap melakukan siklus kedua dengan gambaran hasil sebagai berikut :

\section{Siklus 2}

\section{Tahap Perencanaan}

Berdasarkan hasil refleksi dan evaluasi pelaksanaan tindakan pada siklus I diketahui bahwa pembelajaran Kimia pada materi Hidrolisa Garam yang dilaksanakan pada siklus I belum menunjukan adanya peningkatan motivasi belajar Kimia melalui penggunaan media diagram vee. Oleh karena itu peneliti menyusun rencana pelaksanaan pembelajaran kembali dengan menggunakan media diagram vee dan indikator yang berbeda dengan memaksimalkan siswa bereksplorasi dalam berdiskusi maupun bereksperimen. Beberapa hal dijadikan dasar penyusunan rencana pelaksanaan pembelajaran kembali pada siklus II adalah sebagai berikut: 1) Membuat RPP dengan diagram vee pada garam yang berbeda-beda. 2) Menyiapkan instrumen yang lebih sesuai dengan tujuan pembelajaran. 3) Menunjukan kelemahan dan kekurangan yang dilakukan siswa pada siklus 1. 4) Menyiapkan siswa lebih maksimal dalam bereksperimen dengan memberi kesempatan lebih banyak dan mengamati kerja siswa dengan seksama 5) Mendampingi dan meyakinkan siswa bahwa siswa dapat menyelesaikan tugasnya dengan baik. 6) memberi kesempatan siswa untuk berdiskusi langsung bereksperimen. 7) Menciptakan suasana pembelajaran yang lebih nyaman dan guru lebih tegas dalam menangani siswa yang pasif.

Pada silkus 2 dilaksanakan dalam 3 pertemuan (dengan alokasi waktu setiap pertemuan $2 \times 45$ menit) yaitu pada tanggal 5 April 2016, 7 April 2016 dan 12 April 2016.

\section{Tahap Pelaksanaan / Pengamatan}

Pada tahap ini sesuai dengan rancangan pembelajaran pada RPP menggunakan media diagram vee, pada pertemuan pertama $(2 \times 45)$ terdiri atas : a. Orientasi (5 menit) Sebelum pembelajaran guru terlebih dahulu menyampaikan tujuan pembelajaran dan memotivasi siswa dengan mengulang materi reaksi asam lemah dan basa kuat dan diagram vee yang telah dibuat siswa, kemudian membagi siswa ke dalam kelompok diskusi dan eksperimen. b. Ekplorasi (70 menit) Guru memberi kesempatan pada siswa untuk berdiskusi tentang permasalahan yaitu menentukan sifat garam yang terbentuk rekasi asam kuat dan basa lemah dan menghitung pHnya, dan langsung membuktikan ke dalam eksperimen. c. Konfirmasi (15 menit) Guru meminta peserta didik untuk mengkomunikasikan hasil diskusi dan eksperimen ke dalam diagram vee. Pertemuan kedua a) Orientasi(5 menit) Guru mengulas kembali materi pelajaran yang lalu dan membagi kelompok eksperimen . b) Ekplorasi (70 menit) Guru memberi kesempatan pada siswa untuk berdiskusi tentang permasalahn yaitu menentukan sifat garam yang terbentuk rekasi asam lemah dan basa lemah dan menghitung pHnya, dan membuktikan ke dalam eksperimen. c. Konfirmasi (15 menit) Guru meminta peserta didik untuk mengkomunikasikan hasil diskusi dan hasil ekpsperimen ke dalam diagram vee. Pertemuan ketiga a) Orientasi(5 menit) Guru mengulang kembali materi pelajaran yang lalu dan membagi kelompok . b) Ekplorasi (70 menit). Siswa diberi kesempatan untuk mempresentasikan diagram vee yang dibuat pada pertemuan pertama dan kedua, kelompok lain dan guru memberi penguatan). c) Konfirmasi. (15 menit) Guru meminta peserta didik untuk mengkomunikasikan diagram vee yang dibuat.

\section{Tahap evaluasi}

Pada tahap ini peneliti sekaligus sebagai guru mengadakan evaluasi dengan memberikan tes tulis (bentuk esay). Hasil pengamatan dan evaluasi dapat dilihat pada diskripsi data sebagai berikut :

Deskripsi data prestasi belajar kognitif dan psikomotor pada siklus 2 dapat dilihat dalam tabel dan histogram berikut: 
Tabel 3 Diskripsi Data Hasil Belajar Kognitif dan Psikomotor pada siklus 2

\begin{tabular}{|c|c|c|c|}
\hline \multicolumn{4}{|c|}{ Statistics } \\
\hline & & $\begin{array}{c}\text { Prestasi } \\
\text { belajar } \\
\text { kognitif_- } \\
\text { siklus2 }\end{array}$ & $\begin{array}{c}\text { Prestasi } \\
\text { belajarar } \\
\text { psikomotor_- } \\
\text { siklus2 }\end{array}$ \\
\hline \multirow[t]{2}{*}{$\bar{N}$} & Valid & 20 & 20 \\
\hline & Missing & 16 & 16 \\
\hline \multicolumn{2}{|c|}{ Mean } & 81,50 & 83,00 \\
\hline \multicolumn{2}{|c|}{ Median } & 80,00 & 81,00 \\
\hline \multicolumn{2}{|c|}{ Std. Deviation } & 5,511 & 6,665 \\
\hline \multicolumn{2}{|c|}{ Minimum } & 72 & 75 \\
\hline \multicolumn{2}{|c|}{ Maximum } & 92 & 96 \\
\hline
\end{tabular}

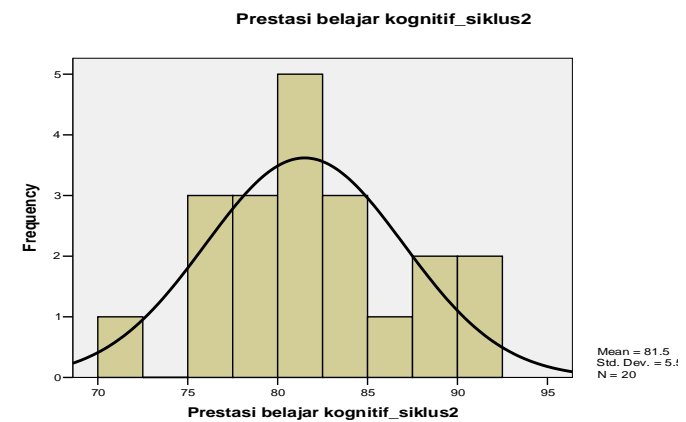

Gambar 3Histogram Nilai Kognitif Siklus 2

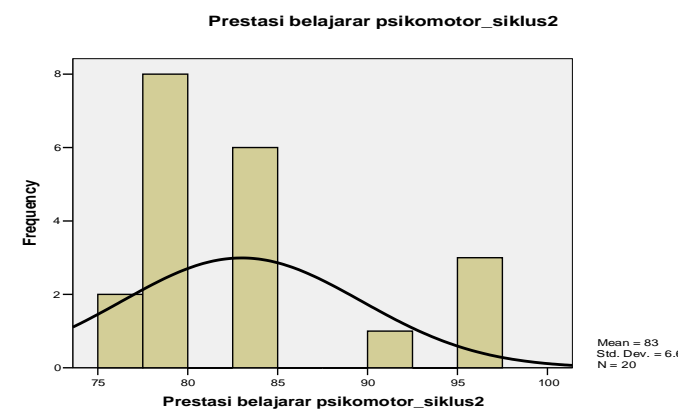

Gambar 4 Histogram Nilai Psikomotor Siklus 1

Sedang data observasi terhadap motivasi belajar siswa pada siklus 2 adalah sebagai berikut :

Tabel 4 Skor Hasil Pengamatan Motivasi Belajar Siswa pada Siklus 2

\begin{tabular}{clcc}
\hline No & Nama Siswa & $\begin{array}{c}\text { Rata-rata } \\
\text { skor }\end{array}$ & Kriteria \\
\hline 1 & Abidin Fajar A. & 81 & Baik \\
\hline 2 & Agustina P. & 81 & Baik \\
\hline 3 & Alfian Dian & 81 & Baik \\
\hline 4 & Ali Fahrudin & 81 & Baik \\
\hline 5 & Antika Dwi H. & 81 & Baik \\
\hline 6 & Arief Krisna & 78 & Cukup \\
\hline 7 & Arif Abdul & 78 & Cukup \\
\hline
\end{tabular}

\begin{tabular}{|c|c|c|c|}
\hline No & Nama Siswa & $\begin{array}{c}\text { Rata-rata } \\
\text { skor }\end{array}$ & Kriteria \\
\hline 8 & $\begin{array}{l}\text { Ayu Dian } \\
\text { Pratiwi }\end{array}$ & 81 & Baik \\
\hline 9 & Bagus Iryawan & 72 & Kurang \\
\hline 10 & $\begin{array}{l}\text { Bambang } \\
\text { Triatmojo }\end{array}$ & 78 & Cukup \\
\hline 11 & Bayu Abdi & 93,75 & $\begin{array}{c}\text { Sangat } \\
\text { Baik }\end{array}$ \\
\hline 12 & Bening Fitri & 81 & Baik \\
\hline 13 & Bimma Ridho & 72 & Kurang \\
\hline 14 & $\begin{array}{l}\text { Bramantya } \\
\text { Ranu Z }\end{array}$ & 81 & Baik \\
\hline 15 & Denis Eka W & 78 & Cukup \\
\hline 16 & Desi Milasari & 78 & Cukup \\
\hline 17 & $\begin{array}{l}\text { Desindra Mala } \\
\text { Dwi }\end{array}$ & 93,75 & $\begin{array}{c}\text { Sangat } \\
\text { Baik }\end{array}$ \\
\hline 18 & Devia Reza & 78 & Cukup \\
\hline 19 & Devi Indra & 81 & Baik \\
\hline 20 & Dian Ariska & 81 & Baik \\
\hline
\end{tabular}

\section{Tahap Refleksi}

Pada siklus dua mulai dari tahap perencanaan sampai tahap evaluasi, kendala masih ditemukan pada siswa yang memang secara internal kurang mampu, utamanya kemampuan memori dan numeriknya. Rasa percaya diri sangat kurang sehingga untuk menumbuhkan motivasi belajar waktu khusus. Guru sudah mengkondisikan pemanfaatan diagramm vee oleh siswa sebagai penghubung teori dan eksperimen. Melalui diagram vee sudah menemukan suatu kebenaran secara teori dan praktek. Secara klasikal pembelajaran menggunakan diagram vee pada materi Hidrolisa Garam meningkatkan motivasi dan hasil belajar siswa, berarti juga pembelajaran menggunakan diagram vee menjadi bermakna. Sehingga penelitian tidak berlanjut pada siklus ke tiga.

\section{B. Pembahasan}

Dari deskripsi dan distribusi data prestasi belajar kognitif pada siklus 1 di atas diperoleh informasi sebagai berikut : rata-rata prestasi kognitif adalah 71,05, dengan simpangan baku 9,891, nilai minimum 50 dan maksimum 84 . Sedang pada penilaian psikomotor pada siklus 1 : rata-rata prestasi kognitif adalah 74 , dengan simpangan baku 10,311, nilai minimum 54 dan maksimum 88. Pada siklus kedua terjadi peningkatan rata-rata prestasi kognitif 81,5, dengan simpangan baku sebesar 5,5, nilai minimum 71 dan nilai maksimum 92, penilaian psikomotor siklus dua rata-rata 83 , simpangan baku sebesar 6,5, nilai minimum 75 dan nilai 
maksimum 96. Berarti ini menunjukkan terjadi kenaikan nilai kognitif dan psikomotor. Hal ini dapat dijelaskan pada pembelajaran siklus kedua siswa diberi kesempatan untuk diskusi langsung membuktikan dengan eksperimen dan menuangkan langsung pada diagram vee. Meskipun garam yang diuji berbeda-beda siswa langsung memahami maksud dari permasalahan yang dihadapi. Mereka memanfaatkan diagram vee untuk menyelesaikan masalah yang dihadapi. Berdasarkan pengamatan peneliti siswa sudah mulai memahami diagram vee, mulai memanfaatkan diagram vee untuk menemukan hubungan pengetahuan dan kerja ilmiah, siswa dapat menghubungkan antara konsep-konsep yang telah diketahui dengan konsep-konsep yang dibangun melalui percobaan di laboratorium.

Berdasarkan data pengamatan motivasi siswa pada siklus 1 (table 4.2), terlihat bahwa skor motivasi siswa 11 orang masih kurang, 6 orang cukup, satu orang baik dan dua orang sangat baik. Pada siklus dua (tabel 4.3) skor motivasi 2 orang kurang, 6 orang cukup, 10 orang baik dan dua orang sangat baik. Hal ini dapat dijelaskan bahwa motivasi belajar siswa terjadi peningkatan, pembelajaran menggunakan diagram vee dapat meminimalkan kendalakendala dan permasahan yang terjadi pada siklus pertama, meskipun belum menunjukkan skor yang sangat baik semua tetapi sudah ada peningkatan jumlah dari yang kurang menjadi baik. Dapat dilihat juga siswa-siswa yang pada siklus 1 motivasinya pada kriteria baik hanya satu orang ternyata pada siklus 2 sudah ada peningkatan menjadi 10 orang. Dalam berkesperimen setiap kelompok sebagian besar siswa sudah terlibat, siswa yang dulu tidak mau bertanya, pada siklus dua mau bertanya tentang apa yang dilakukan. Rasa tidak cepat puas sudah mulai kelihatan, banyak siswa yang melakukan ulang percobaan yang dilakukan, seperti mengukur $\mathrm{pH}$ kembali, menguji sifat larutan dengan kertas lakmus dan membuat diagram vee. Rasa percaya diri siswa terlihat pada saat mengambil larutan dan memegang pipet tetes tangannya tidak gemetar, pada saat diskusi kelompok, kelompok yang presentasi di depat sudah semakin percaya diri dalam mempertahankan pendapatnya yang diakui kebenarannya, sebaliknya kelompok lain semakin berani menyapaikan pendapatnya. Keyakinan merekapun terlihat dalam mengukur $\mathrm{pH}$ menggunakan indikator universal. Meskipun demikian masih ada siswa yang pasif, berdasarkan pengamatan itu terjadi pada siswa secara internal dari diri siswa sudah ada masalah, antara lain kemampuan numeriknya dan memorinya yang kurang. Rasa percaya diri yang masih sangat kurang karena masalah lingkungan di rumahnya. Itulah beberapa hal yang menjadi penyebab mereka kurang termotivasi. Dengan demikian pembelajaran menggunakan diagram vee pada materi Hidrolisa Garam menjadi bermakna

\section{SIMPULAN DAN SARAN}

\section{A. SIMPULAN}

Berdasarkan hasil pengamatan dan pembahasan dapat disimpulkan bahwa pembelajaran kimia pada materi Hidrolisa garam menggunakan media diagram vee secara klasikal dapat meningkatkan hasil belajar kognitif dan psikomotor kelas XI.IPA.1 di SMA Negeri 1 Sukomoro tahun pelajaran 2015/2016 dan meningkatkan motivasi belajar siswa secara klasikal

\section{B. SARAN}

Dalam proses belajar mengajar di SMA, guru harus memiliki strategi dalam memilih media pembelajaran yang tepat dan sesuai dengan karakteristik materi yang diajarkan, agar siswa dapat belajar dengan kreatif, inspiratif, menyenangkan dan menantang. Salah satu langkah yang harus ditempuh harus mencoba menggunakan media pembelajaran dalam proses pembelajaran. Karena penggunaan media pembelajaran yang tepat diharapkan dapat meningkatkan efektifitas dari pembelajaran itu sendiri yaitu membawa siswa dalam kondisi belajar. Berdasarkan kesimpulan dari penelitian ini maka penulis mengajukan saran-saran sebagai berikut :

1. Kepada guru

a. Menggunakan media pembelajaran disesuaikan karakteristik materi yang akan diajarkan

b. Mengecek dan mempersiapkan dari awal tentang strategi, perangkat pembelajaran serta segala sesuatu yang diperlukan untuk mengajar misalnya RPP, LKS, inrtumen penilaian agar proses pembelajaran dapat 
berlangsung dengan lancar dan sesuai dengan tujuan yang diharapkan.

c. Sebelum percobaan dimulai alat yang akan digunakan diteliti sebelumnya supaya dapat digunakan dengan baik selama proses pembelajaran.

d. Memfungsikan metode pembelajaran sebagai perantara guru ke siswa yang berguna untuk memperjelas materi, menghindari miskonsepsi, sehingga pembelajaran dapat membuat siswa berada dalam kondisi belajar.

e. Evaluasi pada materi Hidrolisa garam sebaiknya berupa soal-soal yang mengaplikasikan hasil analisis data percobaan sehingga siswa dapat dengan mudah mengingat apa yang dilakukan dalam bereksperimen

2. Kepada Peneliti

a. Hasil penelitian ini dapat digunakan sebagai reverensi untuk penelitian yang sejenis dengan materi yang berbeda, seperti Termokimia, koloid, elektrokimia, dan sebagainya.

b. Penelitian ini dapat dikembangkan dengan menambah variabel moderator yang lainnya, seperti kemampuan awal, kreatisfitas siswa, kemampuan numerik, kemampuan memori dan sebagainya

3. Kepada Sekolah

a. Sekolah hendaknya memfasilitasi guru dalam mengembangkan pembelajaran menggunakan media pembelajaran yang beragam

b. Sekolah hendaknya memberi keleluasaan bagi guru dalam mengembangkan pembelajaran dengan menggunakan metode-metode pembelajaran yang sesuai dengan karakteristik siswa

\section{DAFTAR PUSTAKA}

[1] Ratna, W D. (1989). Teori-teori Belajar. Jakarta. PT.Erlangga

[2] Michael, P. (2003). Kimia II 2000. Bandung. PT.Erlangga

[3] Apni Viyandari (2012). Pembelajaran IPA Menggunakan Metode Pembelajaran Berbasis Masalah dengan Diagram Vee dan Komik ditinjau dari Kemampuan Memori dan Analisis Siswa https://digilib.uns.ac.id/, diakses tanggal 15 Maret 2015
[4] Budi Utami (2008). Pengaruh Strategi Peta Konsep dan Diagram Vee terhadap hasil belajar siswa pada Pokok Bahasan Larutan Penyangga yang diukur dengan Authentic Assessment. https://www.researchgate.net/.../3283596 69, diakses tanggal 12 April 2015.

[5] Puspita Mega Sari. (2007). Efektiifitas Penggunaan Diagram Vee dan Lembar Kerja Siswa (LKS) dengan Memperhatikan Kreatifitas Siswa pada Materi Larutan Penyannga Kelas XI.IPA. Surakarta. UNS https://core.ac.ik/download/pdf/12349740 /pdf, diakses tanggal 1 April

[6] P. Revianandha (2011), Bab II, Kajian Pustaka. https://eprints.uny.ac.id/21859/0/, diakses pada tanggal 13 April 2105. 